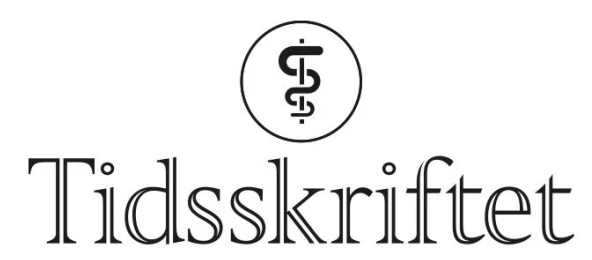

DEN NORSKE LEGEFORENING

\title{
Hvor effektive er covid-19-vaksinene hos eldre?
}

KRONIKK

HANNA HARTMARK VAKSDAL

Hanna Hartmark Vaksdal er medisinstudent ved Universitetet i Oslo.

Forfatteren har fylt ut ICMJE-skjemaet og oppgir ingen interessekonflikter.

\section{GUNNVEIG GRØDELAND}

gunnveig.grodeland@medisin.uio.no

Gunnveig Grødeland er leder for forskningsgruppen Influensa og adaptiv immunitet ved Avdeling for immunologi og transfusjonsmedisin, Universitetet i Oslo og Oslo universitetssykehus.

Forfatteren har fylt ut ICMJE-skjemaet og oppgir ingen interessekonflikter.

\section{Rundt $87 \%$ av den voksne befolkningen i Norge har fătt to doser med vaksine mot covid-19. Nå vaksineres eldre med en tredje dose. Hva særpreger immunsystemet hos eldre personer, og hva vet vi om effekten av vaksinene hos eldre?}

Ved covid-19 er høy alder den viktigste risikofaktoren for alvorlige følger og død (ㅁ). Over $90 \%$ av dødsfallene i Norge har vært blant dem over 6o år, selv om den samme gruppen bare har stått for ca. 8 \% av smittetilfellene (2). Gjennomsnittsalderen for covid-19-assosierte dødsfall i Norge er 81,5 år. Blant dødsfallene over 70 år hadde over halvparten hjerte- og karsykdom og rundt en tredel kronisk lungesykdom (3). Nå tilbys eldre en tredje dose vaksine. Selv om vaksineeffekten er noe redusert hos personer i denne gruppen, vil de fleste likevel oppnå god beskyttelse.

\section{Immunresponser hos eldre}

Vaksiner har gjerne lavere effekt i den eldste delen av befolkningen sammenliknet med resten av befolkningen (4,.5). Det er store individuelle variasjoner i immunsystemet, men ved aldring endres det gjennom en prosess som kalles immunosenescens, dvs. en slags immunologisk alderdom. Man får en redusert evne til å danne nye immunresponser, har en høy andel hukommelsesceller og også ofte en kronisk lavgradig inflammasjon. 
Evnen til å danne nøytraliserende antistoffer vil, for eksempel, reduseres gjennom atrofi av thymus, der T-cellene modnes. Dette reduserer igjen antallet naive T-lymfocytter ( $\underline{6})$. Videre uttrykker færre aktiverte T-lymfocytter hos eldre CD4oL-protein på overflaten, slik at evnen til å aktivere B-celler blir redusert (7,, ). Antallet regulatoriske T-celler synker også (9.). Disse cellene regulerer balansen mellom proinflammatoriske og antiinflammatoriske immunresponser $(\underline{10})$. Når andelen proinflammatoriske mediatorer samtidig er høyere, vil man hos eldre ofte få en lavgradig kronisk inflammasjon (4).

«Selv om vaksineeffekten er noe redusert hos personeri denne gruppen, vil de fleste likevel oppnå god beskyttelse»

Genetikk, fysisk aktivitet, ernæring, mikrobiom, kjønn og cytomegalovirus (CMV)infeksjon ser ut til å være noen faktorer som påvirker immunosenescens (1ㅡ, 12 $)$. Typisk utvikler menn dette tidligere enn kvinner (13). Personer med størst risiko for immunosenescens har også $\emptyset \mathrm{kt}$ risiko for alvorlig covid-19, så her er det en sannsynlig sammenheng (14). Mest utsatt er gjerne eldre menn med diabetes, hjerte- og karsykdom, kols og overvekt. Eldre personer er imidlertid en svært heterogen gruppe, der biologisk og kronologisk alder ikke alltid samsvarer like godt. De fleste av dem får få symptomer og blir lite syke av covid-19.

\section{Kliniske studier}

Flere kliniske studier av effekt av vaksinene har inkludert eldre. Men hvor representative er disse deltakerne for den eldste delen av befolkningen? Studiene til Pfizer og Moderna definerer eldre som personer over 65 år, mens AstraZeneca definerer eldre som personer over 55 år (15-17). De eldre som er med i disse studiene, er friske eller har kontrollerte kroniske sykdommer. Mange eldre i befolkningen passer ikke inn i dette bildet. Det er derfor mulig at de eldre deltakerne i studiene er friskere enn gjennomsnittet i den øvrige befolkningen, og at medianalderen er nærmere 65 år.

Fase 3-studien av Pfizer-vaksinen omfattet flere enn 7700 personer over 65 år, hvorav nesten 16 oo over 75 år. Totaleffekten ble estimert til 94,7\%. Av dem over 75 år var det ingen i vaksinegruppen og kun fem i placebogruppen som fikk påvist SARS-CoV-2-infeksjon. Dette gir et svært bredt konfidensintervall, hvilket innebærer en veldig usikker effektivitet (1ㅡ). I fase 2-studien var imidlertid antistoffnivået nesten dobbelt så stort hos vaksinerte 65-85åringer som hos personer som hadde gjennomgått infeksjon, noe som viser lovende vaksineeffekt (18).

Fase 3-studien for mRNA-vaksinen fra Moderna omfattet rundt 7100 deltakere over 65 år. Medianalderen ble ikke oppgitt. Det var 29 personer blant de eldre som fikk påvist SARSCoV-2 i placebogruppen og 4 i vaksinegruppen, noe som gir en effektivitet på 86,4\%. Effekten i denne aldersgruppen ser ut til å være ganske lik som for Pfizer-vaksinen (15). Fase 2-studien viser også for denne vaksinen gode immunresponser hos de eldre (19).

\section{Befolkningsstudier}

Ettersom de kliniske studiene ikke ga sikre konklusjoner på effekt blant de eldste, er det ekstra viktig å undersøke hvordan denne gruppen beskyttes etter vaksineutrulling i befolkningen. Studier fra Israel viste tidlig svært lovende resultater for den eldre

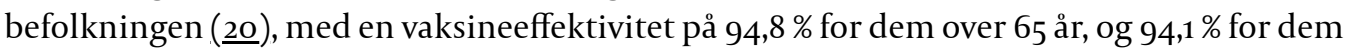
over 85 år. Til sammenlikning var effekten hhv. 96,1\% og 94,9\% for aldersgruppene 16-44 og 45-64 år (므). Da denne studien ble gjennomført i Israel, var det alfavarianten av viruset

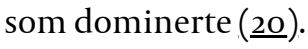


«Ettersom de kliniske studiene ikke ga sikre konklusjoner på effekt blant

de eldste, er det ekstra viktig å undersøke hvordan denne gruppen

beskyttes etter vaksineutrulling i befolkningen»

I Danmark har man undersøkt vaksineeffekt i fem prioriterte grupper etter utrulling av vaksinene: sykehjemsbeboere, individer over 65 år med behov for hjemmesykepleie, eldre over 85 år, helsearbeidere og individer med komorbiditet (21). Effekten mot infeksjon ble estimert til hhv. $53 \%, 86 \%, 77 \%, 80 \%$ og $71 \%$. Helsearbeidere, her med medianalder på 49 år, var signifikant bedre beskyttet enn sykehjemsbeboere (med medianalder 84 år). Det er imidlertid grunn til å understreke at vaksinen i alle aldersgrupper beskyttet veldig godt mot covid-19-relatert sykehusinnleggelse og $\mathrm{d} ø \mathrm{~d}$, og at den laveste effekten var hos

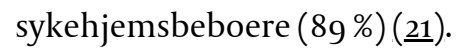

I Skottland har man brukt både Pfizer-vaksinen og AstraZeneca-vaksinen i vaksinasjonsprogrammet (르). Der ble vaksineeffekten mot sykehusinnleggelse etter én dose estimert til 92 \% for personer mellom $18-64$ år, 93 \% for 65-79 år og $83 \%$ for dem over 80 år. Effekten etter én dose ser dermed ut til å være svært tilfredsstillende, også i den eldre

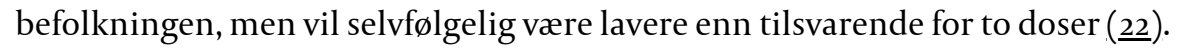

I England ble de samme vaksinene benyttet som i Skottland, og i en studie av effekt hos eldre over 70 år etter vaksinering gjennom vaksinasjonsprogrammet estimerte man rundt $60 \%$ beskyttelse etter første dose og 85-90 \% etter andre dose (23). For vaksinerte som ble smittet, var sannsynligheten for å bli innlagt $44 \%$ lavere enn blant uvaksinerte, og sannsynligheten for $\mathrm{d} ø \mathrm{~d} 51 \%$ lavere. Denne studien omfattet kun personer som ble testet grunnet symptomer på covid-19, og alfavarianten var dominerende på dette tidspunktet (23).

I USA har man brukt vaksinene fra både Pfizer og Moderna. Ved å hente inn tall på innleggelser fra 24 sykehus i 14 stater ble effekten av vaksineringen mot alvorlig sykdom hos personer over 65 år (medianalder 73 år) estimert til 94 \% etter fullvaksinering og $64 \%$ etter én vaksinedose (24).

\section{Oppsummering}

Valg av behandling følger sjelden kronologisk alder. En person blir ikke en geriatrisk pasient på bakgrunn av alder alene, men gjennom en kombinasjon av komorbiditet, kognitiv funksjon, aktivitet i dagliglivet og medikamentbruk. For SARS-CoV-2-vaksinering har man gått etter kronologisk alder. Dette er en naturlig avgrensning for å få et håndterbart system, men også fordi eldre utpeker seg som en klar risikogruppe.

Summen av data fra kliniske studier og befolkningsstudier viser at effekten av vaksinene mot SARS-CoV-2 er veldig god, spesielt hva gjelder å forhindre sykehusinnleggelse og død. Likevel ser vi nå en liten økning i antall innleggelser blant vaksinerte eldre (205). Årsakene er mange og sammensatte, men de mest utsatte personene er også de som typisk har kommet lengst i utviklingen av immunosenescens.

«Alle data så langt peker på at fullvaksinerte eldre er godt beskyttet mot både alvorlig sykdom og død»

I Norge har helsemyndighetene igangsatt vaksinering med en tredje dose for eldre over 65 år. Det er usikkert hvor lenge effekten av denne dosen vil vare, men den vil sikkert øke mengden nøytraliserende antistoffer i serum på nytt. Disse antistoffene vil kunne beskytte også mot mildere sykdom, men antistoffnivåene vil reduseres over tid. For eldre kan det likevel være nyttig å få økt nivåene av nøytraliserende antistoffer når vi nå går inn i en 
sesong preget av smitteøkning både fra SARS-CoV-2 og influensavirus. Samtidig må man minne om at vaksinene har som sin primære hensikt å danne hukommelsesresponser. Når vi eksponeres for virus (eller ny vaksinedose), vil hukommelsescellene igangsette produksjon av beskyttende antistoffer og T-celler. Alle data så langt peker på at fullvaksinerte eldre er godt beskyttet mot både alvorlig sykdom og død.

\section{LITTERATUR}

1. Himmels JPW, Borge TC, Brurberg KG et al. COVID-19: COVID-19 and risk factors for hospital admission, severe disease and death [Covid-19 og risikofaktorer for sykehusinnleggelse, alvorlig sykdom og død - en hurtigoversikt, fjerde oppdatering.] Oslo: Folkehelseinstituttet, 2021. https://www.fhi.no/en/publ/2021/COVID-19-risk-factors-hospital-admission-severe-disease-death-4thupdate/ Lest 2.11.2021.

2. Folkehelserapportens temautgave 2021. Folkehelsen etter covid-19. Pandemiens konsekvenser for ulike grupper i befolkningen. Oslo: Folkehelseinstituttet, 2021.

https://www.fhi.no/contentassets/b669dobbb94943efae9793b33526d415/folkehelserapportenstemautgave-2021---folkehelsen-etter-covid-19.pdf Lest 2.11.2021.

3. Strøm MS, Raknes G. Tall for covid-19 assosierte dødsfall i Dødsårsaksregisteret i 2020. Folkehelseinstituttet. https://www.fhi.no/hn/helseregistre-og-registre/dodsarsaksregisteret/tall-forcovid-19-assosierte-dodsfall-i-dodsarsaksregisteret-i-2020/ Lest 2.11.2021.

4. Santoro A, Bientinesi E, Monti D. Immunosenescence and inflammaging in the aging process: agerelated diseases or longevity? Ageing Res Rev 2021; 71: 101422. [PubMed][CrossRef]

5. Tanner AR, Dorey RB, Brendish NJ et al. Influenza vaccination: protecting the most vulnerable. Eur Respir Rev 2021; 30: 200258. [PubMed][CrossRef]

6. Palmer DB. The effect of age on thymic function. Front Immunol 2013; 4:316. [PubMed][CrossRef]

7. Elgueta R, Benson MJ, de Vries VC et al. Molecular mechanism and function of CD4o/CD4OL engagement in the immune system. Immunol Rev 2009; 229: 152-72. [PubMed][CrossRef]

8. Colonna-Romano G, Bulati M, Aquino A et al. B cells in the aged: $\mathrm{CD}_{27}, \mathrm{CD}_{5}$, and $\mathrm{CD}_{4} 0$ expression. Mech Ageing Dev 2003; 124:389-93. [PubMed][CrossRef]

9. Schmitt V, Rink L, Uciechowski P. The Th17/Treg balance is disturbed during aging. Exp Gerontol 2013; 48: 1379-86. [PubMed][CrossRef]

10. Josefowicz SZ, Lu LF, Rudensky AY. Regulatory T cells: mechanisms of differentiation and function. Annu Rev Immunol 2012;30: 531-64. [PubMed][CrossRef]

11. Bosco N, Noti M. The aging gut microbiome and its impact on host immunity. Genes Immun 2021; 22: 289-303. [PubMed][CrossRef]

12. Nieman DC, Wentz LM. The compelling link between physical activity and the body's defense system. J Sport Health Sci 2019; 8: 201-17. [PubMed][CrossRef]

13. Ostan R, Monti D, Gueresi P et al. Gender, aging and longevity in humans: an update of an intriguing/neglected scenario paving the way to a gender-specific medicine. Clin Sci (Lond) 2016; 130: 1711-25. [PubMed][CrossRef]

14. Chen Y, Klein SL, Garibaldi BT et al. Aging in COVID-19:Vulnerability, immunity and intervention. Ageing Res Rev 2021; 65: 101205. [PubMed][CrossRef]

15. Baden LR, El Sahly HM, Essink B et al. Efficacy and safety of the mRNA-1273 SARS-CoV-2 vaccine. N Engl J Med 2021; 384: 403-16. [PubMed][CrossRef]

16. Polack FP, Thomas S], Kitchin N et al. Safety and efficacy of the BNT162b2 mRNA covid-19 vaccine. N Engl J Med 2020; 383: 2603-15. [PubMed][CrossRef]

17. Voysey M, Clemens SAC, Madhi SA et al. Safety and efficacy of the ChAdOx1 nCoV-19 vaccine (AZD1222) against SARS-CoV-2: an interim analysis of four randomised controlled trials in Brazil, South Africa, and the UK. Lancet 2021;397: 99-111. [PubMed][CrossRef]

18. Walsh EE, Frenck RW, Falsey AR et al. Safety and immunogenicity of two RNA-based covid-19 vaccine candidates. N Engl J Med 2020;383: 2439-50. [PubMed][CrossRef]

19. Anderson EJ, Rouphael NG, Widge AT et al. Safety and immunogenicity of SARS-CoV-2 mRNA-1273 vaccine in older adults. N Engl J Med 2020;383: 2427-38. [PubMed][CrossRef]

20. Haas EJ, Angulo FJ, McLaughlin JM et al. Impact and effectiveness of mRNA BNT162b2 vaccine against SARS-CoV-2 infections and COVID-19 cases, hospitalisations, and deaths following a 
nationwide vaccination campaign in Israel: an observational study using national surveillance data. Lancet 2021; 397: 1819-29. [PubMed][CrossRef]

21. Emborg HD, Valentiner-Branth P, Schelde AB et al. Vaccine effectiveness of the BNT162b2 mRNA COVID-19 vaccine against RT-PCR confirmed SARS-CoV-2 infections, hospitalisations and mortality in prioritised risk groups. medRxiv. Preprint 2.6.2021.

https://www.medrxiv.org/content/10.1101/2021.05.27.21257583v1 Lest 2.11.2021.

22. Vasileiou E, Simpson CR, Shi T et al. Interim findings from first-dose mass COVID-19 vaccination roll-out and COVID-19 hospital admissions in Scotland: a national prospective cohort study. Lancet 2021; 397: 1646-57. [PubMed][CrossRef]

23. Lopez Bernal J, Andrews N, Gower C et al. Effectiveness of the Pfizer-BioNTech and OxfordAstraZeneca vaccines on covid-19 related symptoms, hospital admissions, and mortality in older adults in England: test negative case-control study. BMJ 2021; 373: n1088. [PubMed][CrossRef]

24. Tenforde MW, Olson SM, Self WH et al. Effectiveness of Pfizer-BioNTech and Moderna vaccines against COVID-19 among hospitalized adults aged $\geq 65$ years - United States, January-March 2021. MMWR Morb Mortal Wkly Rep 2021; 70: 674-9. [PubMed][CrossRef]

25. Mizrahi B, Lotan R, Kalkstein N et al. Correlation of SARS-CoV-2 Breakthrough Infections to Timefrom-vaccine; Preliminary Study. medRxiv. Preprint 31.7.2021.

https://www.medrxiv.org/content/10.1101/2021.07.29.21261317v1 Lest 2.11.2021.

Publisert: 15. november 2021. Tidsskr Nor Legeforen. DOI: 10.4045/tidsskr.21.0748

Mottatt 21.10.2021, første revisjon innsendt 1.11.2021, godkjent 2.11.2021.

(C) Tidsskrift for Den norske legeforening 2023. Lastet ned fra tidsskriftet.no 26. april 2023. 